\title{
7
}

\section{Conceptualizing National Family Policies: A Capabilities Approach}

\author{
Jana Javornik and Mara A. Yerkes
}

Comparative family policy research has advanced significantly in recent years. The growing availability of more and better data have improved our understanding of cross-national similarities and differences in family policies, as well as how they shape the lives of different families and children, also evidenced by various chapters in this handbook. Despite advancements, comparative family policy research continues to face difficulties. For example, empirical analyses largely include "standard" measures tailored to dual-earner heterosexual couples because the multifaceted nature of family policies makes cross-country comparisons complex. Such analyses fail to reflect policy logics, and few studies use legal formulations to capture the state's underlying assumptions and differential statutory entitlements (Javornik, 2014; but see Chapter 12 by Skinner \& Hakovirta and Chapter 16 by Evertsson, Jaspers, Moberg in this volume). Moreover, comparative policy analyses often face problems conceptualizing family policies as well as operationalizing them into measurable indicators (Yerkes \& Javornik, 2019; see Chapter 6 by Zagel \& Lohmann in this volume).

\section{J. Javornik (凶)}

Leeds University Business School, University of Leeds, Leeds, UK e-mail: J.Javornik@leeds.ac.uk

\section{A. Yerkes}

Department of Interdisciplinary Social Science, Utrecht University, Utrecht, The Netherlands

e-mail: m.a.yerkes@uu.nl 
In this chapter, we offer an innovative approach to comparing family policies using the capability approach (capability approach). From a capabilities perspective, individuals are embedded in broader, relational contexts; these ecological and social contexts shape the real opportunities individuals have (Javornik \& Kurowska, 2017). Thus, what individuals are really able to do and be is a reflection of their capabilities, their agency, and choice (Robeyns, 2017), within the diverse contexts in which individuals are embedded (Hobson, 2014; Hvinden \& Halvorsen, 2018). Applying the capability approach (Nussbaum, 2000, 2011; Robeyns, 2005, 2017; Sen, 1992, 1999a) to family policy analysis offers a promising evaluative perspective for comparatively investigating the extent to which policy design empowers parents to freely use its instruments, or, to what extent its design enhances the capabilities of parents; in other words, what parents are truly able to do and be (Sen, 1992). ${ }^{1}$ Using examples of childcare policies in Sweden and the UK, a policy area particularly prone to conceptual challenges, we discuss the difficulties involved in conceptualizing family policies in comparative research. Childcare services, as a key component of family policy (Yerkes \& Javornik, 2019), intertwine with other policy domains such as employment, gender equality, demography, and the tax system. Such policy complexity creates comparative challenges for empirically investigating childcare services across countries. It also creates difficulty in disentangling what key aspects of childcare policy mean for different groups of parents. The latter is crucial, as childcare service provision shapes the conditions under which parents can access and engage with employment or other opportunities (e.g., education). The two countries investigated here, Sweden and the UK, differ in one salient aspect: while Sweden uses a public-provision mechanism through demandpriming approach, the UK has been reforming its supply-led, marketized childcare system (Yerkes \& Javornik, 2019). This, as shown in our earlier work, has significant ramifications for parents' childcare capabilities.

The capability approach is increasingly used in social policy research (Yerkes, Javornik, \& Kurowska, 2019) and in family policy scholarship in particular (see also chapter 19 by Schober in this volume). For example, it is applied in relation to work-family policy (Chatrakul, Ayudhya, Prouska, \& Beauregard, 2017; den Dulk \& Yerkes, 2016; Fahlén, 2013; Hobson, 2014; Korpi, Ferrarini, \& Englund, 2013; Yerkes \& den Dulk, 2015), more recently to parental leave policy (Javornik \& Kurowska, 2017; Javornik \& Oliver, 2019; Koslowski \& Kadar-Satat, 2019; Kurowska \& Javornik, 2019) and in reconceptualizing the (de)familialism perspective in comparative family

\footnotetext{
${ }^{1}$ While we recognize that family policy affects children's well-being, our focus here is on parental perspective.
} 
policy research (Kurowska, 2018). To date, only one study has applied the capability approach to comparative childcare policy (Yerkes \& Javornik, 2019), and this chapter builds on this earlier work. We start by outlining the capability approach, and the advantages of using the capability approach for evaluating family policies in comparative perspective. We then conceptualize key policy aspects taking the capability approach perspective and discuss their various implications along gendered and classed lines.

\section{The Capability Approach: Background and Application}

Sen developed the capability approach by drawing on the moral and political philosophy of Aristotle, Smith, and Marx (Sen, Hanžek \& Javornik, 2002). This perspective shows a dual concern: a philosophical concern for social justice and the human good, and an economic concern for measuring life quality, as well as promoting autonomy and pluralist individual life choices. The political philosophy of Aristotle, whose key principle was human flourishing as ethically fundamental, lies at the heart of the capability approach (Nussbaum, 1987). Further developed through moral and political philosophy, the capability approach values pluralist life courses (Robeyns, 2017), promoting the idea of individuals "in need of a totality of life activities" and real freedoms to pursue those (Nussbaum, 1987). Ultimately, the freedom to achieve well-being is of moral importance and viewed in relation to people's capabilities - their real opportunities to do and be what they have reason to value (Yerkes et al., 2019). Emphasizing capabilities, or individual freedom to achieve a wider range of valued outcomes, shifts the focus away from purely economic measures of utility toward other valued outcomes and individual capabilities to pursue these activities. Work-family scholarship, for example, shows couples may value relationship harmony over gender egalitarian divisions of labor (Baxter, 2000; Thompson, 1991). Similarly, mothers may be willing to sacrifice career opportunities in the short term because they value flexible working arrangements upon returning to work after childbirth (Yerkes, Martin, Baxter, \& Rose, 2017). The capability approach is a flexible and multi-purpose framework (Sen, 1992, p. 48), useful for moving comparative analysis beyond childcare policy as a means for work-family reconciliation toward understanding childcare policy in relation to parents' capabilities to live the life they have reason to value. To apply the capability approach effectively in family policy research, further specification of the framework is needed. Namely, the capability approach is "open-ended because 
the general capability approach can be developed in a range of different directions, with different purposes, and it is underspecified because additional specifications are needed before the capability approach can become effective for a particular purpose" (Robeyns, 2017, p. 29; emphasis in original).

\section{Key Elements of a Capability Approach to Family Policy}

The capability approach (Sen, 1992, 1999a) centers around multiple concepts, with five being key to its application: means, capabilities, functionings, conversion factors, and agency (cf. Robeyns, 2005). Means are the various resources (e.g., economic, social) to which individuals have access. Inequality can arise due to variation in means. However, even when individuals have equal access to means, they may not have the same capabilities, i.e., real opportunities or potential, to live the life one has reason to value. Capabilities, what people are able to do or be (Robeyns, 2017) thus differ from what individuals actually achieve (functionings, or achieved functionings). Inequalities can arise out of variation in means but also because individuals are not equally able to translate means into capabilities. The translation from means into capabilities is shaped by conversion factors, i.e., the multiple contexts in which individuals are embedded at the personal, community, and societal level (e.g., Robeyns, 2005, 2017; Yerkes, Hoogenboom, \& Javornik, 2019). Personal conversion factors include aspects such as gender, class, race/ethnicity, age, and health. Community level conversion factors refer to relationships at the local level (e.g., social networks) as well as the places and spaces in which individuals are embedded (Yerkes et al., 2019). Societal level conversion factors include social norms and social movements (Hobson, 2014). Combined, these conversion factors enhance or constrain the set of real opportunities individuals can choose from (the capability set in capability approach terms). Inequalities in what individuals are able to achieve can also be attributed to inequalities in agency. Agency or the way in which individuals perceive, interpret, and respond to their social situation (Giddens, 1984; Mead, 1934) can be seen as the freedom to act, and reflects individual's active response in social situations (Sen, 1999b; Shaw, 1994). The reflexive interaction with the world (agency-structure) can be seen as a mutual constitutive process of structuration (Giddens, 1984). For example, men and women from different social classes may use family policy differently because gender 
and class inhibit or enhance their agency. At the same time, gender and social class as a social structure may shape individual behavior. The capability approach emphasizes such relational aspects, seeing individuals with differing freedoms to act (inequalities in agency) as relationally embedded in personal and social contexts (conversion factors).

A successful application of the capability approach in comparative family policy research requires first and foremost accounting for the role of policy itself. At present, social policies, including family policies, are largely interpreted and applied in three ways: as conversion factors and as structural constraints (Hobson, 2014; Robeyns, 2017), and/or as a means to facilitate capability (Javornik \& Kurowska, 2017; Kurowska, 2018; Yerkes \& Javornik, 2019; Yerkes et al., 2019). Traditional applications of the capability approach (e.g., Robeyns, 2005, 2017) view policy as a structural constraint. In this scholarship, policy is viewed as an interdependent set of measures and instruments aiming to change human behavior and/or improve quality of life and well-being. Initial applications of the capability approach to family policy, such as Hobson's (2014) capabilities framework for work-life balance, treat policies as part of the social context, whereby parents' use of policies is seen to differ based on their perceived set of alternatives available and the sense of entitlement to use these policies (Hobson, 2018). Later applications by Hvinden and Halvorsen (2018) and Kurowska (2018) suggest policies are both conversion factors and means. For example, parental leave and childcare policies can function as a means that facilitates parent's capabilities to arrange care in a way they have reason to value (Javornik \& Kurowska, 2017; Kurowska, 2018; Yerkes \& Javornik, 2019; Yerkes et al., 2019). What role policy plays depends upon the context of the research question at hand (Hvinden \& Halvorsen, 2018; Kurowska, 2018), similar to the differing roles variables can take on in empirical research (e.g., mediator, moderator).

For the purpose of this chapter, we see family policy as a means for parents to arrange childcare in a valued way. The translation of this means into real opportunities is shaped by gender and class, thereby affecting parents' capabilities (Yerkes \& Javornik, 2019). These capabilities will differ across parents. For some parents, public childcare creates the means to better reconcile work and care (Gornick \& Meyers, 2003; Grönlund \& Javornik, 2014); for others, it creates the means to use childcare as an aspect of children's development needs and socialization (OECD, 2017b; Saraceno, 2011; van Huizen \& Plantenga, 2015). Equally, it reduces the need for family care to enable other meaningful contributions to society (e.g., education, training, 
job search, or volunteering) (Javornik \& Ingold, 2015). Conceptualizing policies in this way means understanding family policies in diverse, historical, and political contexts (Ginsburg, 2004) as value-laden, developed based on culturally informed, dominant ideas (Béland, 2005, 2016). Crucially, policies provide normative reference points (Goerne, 2010; Javornik, 2014) that set the "rules of the game" (North, 1990). That is, policies define what means are available to parents in a specific country, and the capability approach helps to analyze whether they help individuals to achieve that normative reference point.

However, individuals do not have the same real opportunities (capabilities) to achieve varying life pursuits, which leads to inequality in outcomes, or achieved functionings (Sen, 1992). Social policy scholars largely view capabilities in Sen's (1992) terms of valued functionings, or the real opportunities individuals have to pursue a life they have reason to value (Yerkes et al., 2019). Similar interpretations can be useful for applications to family policy. For example, an individual may value being a carer and places greater value on providing care than on participating in paid employment. The capability approach rests on the idea that individuals have an array of valued functionings, reflecting diverse needs and desires. Individuals are not equally able to pursue these valued life activities, which leads to inequalities in outcomes or achieved functionings. As outlined by Robeyns (2017, pp. 41-45), capabilities and functionings can be either positive or negative, and thus must be viewed as essentially value neutral in the abstract sense. While in some cases we might be able to distinguish positive functionings (e.g., gender equality at work) or negative functionings (e.g., female double burden), the value of functionings is often ambiguous. Assuming that family policy aims to facilitate a positive functioning for most parents, this same policy can lead to unintended negative functionings for some groups or individuals.

How childcare policy translates to parents' capabilities depends on conversion factors at multiple levels (as above). For example, parents wishing to reconcile work and care often do so within the context of their workplace. Organizational practice, with dominant norms of an ideal worker, influences one's "sense of entitlement" to make use of available policies (Grönlund \& Javornik, 2014; Hobson, 2014). While we recognize the role of cultural, societal, community, and organizational contexts as well as personal history and circumstances as conversion factors in parents' capabilities, in this chapter we focus on gender and class, two key individual-level conversion factors operating in intersectional ways (e.g. Hook, 2015; Korpi et al., 2013). Namely, childcare costs constrain childcare capabilities of lower 
socio-economic classes, limiting their ability to choose high-quality childcare (Morgan, 2005). Similarly, low accessibility or availability can make childcare exclusive, maintaining gendered patterns of care (Kreyenfeld \& Hank, 2000). Given educational homogamy among couples (Steiber \& Haas, 2009), childcare capabilities relate to the intersection of class and gender. With education as a proxy for class in work-family arrangements (Hook, 2015), mothers with higher levels of education have more opportunities to arrange childcare, relative to mothers constrained by economic need (Steiber \& Haas, 2009). In contrast, highly educated mothers generally have stronger labor market attachment and higher opportunity costs from opting out of work and staying home to provide care (Hook, 2015). Our approach allows us to highlight variation and any tensions between key aspects of childcare policy and how this affects parents in relation to gender and class.

Evaluating childcare policies from a capabilities perspective means not only viewing individuals in relation to the social spaces in which they are embedded, but also the relational nature of social rights embedded in childcare policies. In the former, individuals may be supported or limited in their capacity to access childcare as a means to achieve a valued outcome given personal, social, or environmental factors (Hvinden \& Halvorsen, 2018). Thereby, childcare policies inherently create inequalities through a process of exclusion given varying degrees of selectivity. However, policies are relational and interdependent and often accessible only through other policies. In the UK, for example, subsidised childcare for under-3s is only available to families in receipt of low-income benefits, i.e., childcare is dependant upon social policy criteria. It is thus unavailable/unaffordable to many parents who may wish or need childcare sooner, which affects the demand for parental leave (similarly to other countries). These examples demonstrate the relational aspect of the capability approach, focusing on the interconnectedness of parents' decision-making about childcare. It demonstrates that policy can be part of a broader social context that shapes individuals' access to other policy instruments. Against this backdrop, the question of accessibility becomes central because it shapes parents' freedoms, and is thus indicative of distributive justice. Namely, to fully use the policy, one needs to be aware of a web of policy options and be able to navigate the legal landscape. This entails understanding (1) the policy process (functional literacy), (2) the relational aspects of social rights (i.e., how one affects another), and (3) the power dynamics between them (which and whose right superceeds) (Yerkes et al., 2019).

Our suggested application of the capability approach in family policy research builds on previous work in this area. Earlier applications of the capability approach have been framed as challenging a dominant utility 
perspective and highlighting differential constraints on choice and agency. Specifically, in relation to parental leave, Javornik and Kurowska's (2017) analytical framework aims to enable a comparative analysis of parents' real opportunity to take parental leave in the context of given policy entitlements and the impact of social norms in relation to both gender and class. Javornik and Oliver's (2019) legislative analysis of the UK shared parental leave seeks to understand leave in a broader legal context, which created "material and discursive opportunities" for shared parenting. Hobson, Fahlen and Takacs (2011, p. 169) consider discursive space in the context of workfamily policies and how policy entitlements translate into an individual "sense of entitlement". Authors argue that by challenging gender norms at a cognitive level (of agency), policy framing facilitates agency and challenges gender norms, making the use of policy "possible." Chatrakul et al. (2017) further demonstrate how this "sense of entitlement" is shaped by social and economic circumstances, functioning as a cognitive filter to influence one's agency and capabilities in reconciling work and family life. To exemplify, when a policy instrument is removed from cultural norms, familial values, or organizational practice and culture (Grönlund \& Javornik, 2014), individuals may not value or use it.

Earlier studies highlight the multiple interpretations and applications of the capability approach in family policy research, in particular with varying emphasis on policies, workplaces, the "sense of entitlement," or conversion factors, as well as variation in interpreting policy as an institutional conversion factor or a means. Some of this divergence can be explained by two varying approaches to the capability approach: Sen's and Nussbaum's. Sen's perspective is essentially economic and philosophical, emphasizing questions around the pursuit of the "good life" (that which people have reason to value) and measurements of life quality. Nussbaum's perspective, in contrast, is moral-legal-political philosophical, arguing that governments should guarantee a given set of "basic" human capabilities (Nussbaum, 2000).

Our application of the capability approach to family policy follows Sen's perspective. While we recognize the value of both approaches, we use Sen's for its emphasis on the role of agency in creating inequalities in capabilities. Furthermore, we demonstrated above how domain-specific knowledge in the family policy field is required to inform the application of the capability approach in comparative family policy research. Similar to the application of the capability approach to countries' national childcare policies in our earlier study (Yerkes \& Javornik, 2019), such domain-specific knowledge provides building blocks for further specification of capability "theories" within the family policy field. 


\section{Operationalizing and Evaluating Childcare Capabilities}

To apply the capability approach as an evaluative empirical framework, we focus on childcare policy as a means, and how aspects of childcare policy design interact with the conversion factors of gender and class to create varying childcare capabilities. A similar approach can be taken in future family policy studies, using domain-specific knowledge to identify the relevant aspects of policy design that potentially interact with conversion factors to create variation in capabilities. For childcare, based on our earlier research and established gendered welfare state scholarship, we argue that direct public service provision offers parents across socio-economic groups the best opportunities to arrange childcare in ways they have reason to value because it provides real opportunities (Leitner, 2003; Lister, 1997; Saraceno \& Keck, 2010; see also Chapter 8 by Vandenbroeck in this volume). Against this background, we focus on national childcare services across five most salient features of its potential as a means: availability, accessibility, affordability, quality, and flexibility (Bonoli \& Reber, 2010; Ciccia \& Bleijenbergh, 2014; Daguerre, 2006; Eydal \& Rostgaard, 2011; Gislason \& Eydal, 2011; Gornick \& Meyers, 2003; Gornick, Meyers, \& Ross, 1998; Javornik, 2010, Javornik, 2014; Plantenga \& Remery, 2005, 2009; Saraceno, 2011). Our underlying assumption is that availability, accessibility, and affordability are key to childcare capabilities, and that quality and flexibility become an issue once childcare is available and accessible, and are often a reflection of affordability (Kreyenfeld \& Hank, 2000; Morgan, 2005; Verhoef, Tammelin, May, Rönkä, \& Roeters, 2016).

Ideally, we would use data that best allow us to illustrate the capability approach applicability to comparative childcare policy analysis. However, available and commensurable data have several shortcomings, such as a focus on the public sector, and hence an absence of private sector data, spending profiles which cover multiple services and programs, and variation in what actually gets measured (Fagan \& Hebson, 2005; Javornik, 2014; Keck, Hessel, \& Saraceno, 2009; Lambert, 2008; Mätzke, Brokking, Anntonen, \& Javornik, 2017; OECD, 2018; Plantenga \& Remery, 2005). Considering these issues, we use multiple data sources (Eurostat, 2017; Eurydice, 2018; Multilinks, 2011; OECD, 2017a, 2017b, 2018; Plantenga \& Remery, 2005, 2009, 2013, 2015; SPIN, 2019) and single country reports to provide a comprehensive analysis; arguably, better data will, in the future, enable improved analyses, and our work seeks to contribute to these efforts (see also Chapter 24 by Sirén, Doctrinal, Van Lancker and Nieuwenhuis in this volume). 


\section{Availability}

Childcare availability is integral to parents' employment, particularly mothers', but it also plays a key role in child development (OECD, 2017b; Plantenga \& Remery, 2009; Saraceno, 2011; van Huizen \& Plantenga, 2015). Analyzing availability is complex because of different types of care provision available in each country. Moreover, countries combine formal and semi-formal provisions, offer subsidized arrangements outside nurseries, registered playgroups, and a mix thereof. In earlier research, availability is largely operationalized using enrolment rates. We find this problematic because it conflates structural differences in care provisions by focusing on a single outcome (Javornik, 2014). A more useful approach distinguishes logics of care provision (Brennan, Cass, Himmelweit, \& Szebehely, 2012), including logic of non-familial care through market provision (for profit), state provision, and associations, whereby childcare is offered by formal private or non-profit organizations. We argue that public-and market-provision mechanisms have different consequences for parents' capabilities, and address this by combining data on the problematic yet most commonly used measure for availability (enrolment rates for 0-2-year olds and 3-6-year olds) with a classification of countries based on their prevailing provision mechanism.

\section{Accessibility}

Comparative studies on childcare typically rely on capacity (the number of places available) as a proxy for service accessibility (Plantenga \& Remery, 2015). However, to identify the potential for social inclusion/exclusion from public service, we need to understand admission criteria, i.e., the construction of a right to childcare (Jensen, 2009). Namely, selective practices (using preferential criteria) and provider autonomy can create tensions and diminish childcare capabilities (Javornik, 2014). In contrast, national-level capacity planning could reduce disparities between geographical units (OECD, 2018; Plantenga \& Remery, 2005, p. 35). Furthermore, childcare is accessible when it is offered as a right attached to children rather than conditional (Saraceno, 2011). Childcare subsidies tied to eligibility criteria (e.g., parents' employment) create an opportunity gap for parents in education or training, or seeking a job, starting a business or volunteering. Having childcare in place is essential before parents can undertake such activities (Javornik \& Ingold, 2015). When childcare placement is provided as a child's right, policy "stresses societal responsibility to grant all children adequate family care and 
time, as well as non-family resources for the full development of their capabilities," which improves parents' childcare capabilities, particularly across class (Saraceno, 2011, p. 92). Furthermore, and drawing on Gornick and Meyers (2003) and Javornik (2014), policy that guarantees a place to all children (child's right) without delays and gaps between paid leave and childcare improves childcare capabilities. When a child can be refused a place based on preferential criteria (e.g., family composition, income, parental employment status), service provision is likely to vary (Fagan \& Hebson, 2005), hindering access to public service. Lastly, policy that enhances childcare capabilities opens care service before the end of paid leave or at least coordinates the two (Javornik, 2014; Javornik \& Kurowska, 2017). Thus, a measure of accessibility should focus on admission requirements, including the allocation of places and admission age, to be evaluated in relation to parental leave and its intertwining with childcare service accessibility.

\section{Affordability}

From a policy perspective, providing affordable childcare is seen as key to promoting mothers' employment. Understandably so, as childcare costs are the equivalent of a regressive tax on mothers' labor supply and reduce financial returns from employment (Esping-Andersen, 2009). In practice, free childcare services practically do not exist. As a result, funding mechanisms are crucial for childcare capabilities. Earlier studies predominantly measure affordability by public spending. Such measures are problematic as they reflect national funding streams to finance services (OECD, 2016a). These measures generally do not capture other funding sources, e.g., when local governments do not report on childcare spending (e.g., Gornick \& Meyers, 2003; Javornik, 2014; Lambert, 2008) or when services are funded through collective bargaining agreements (Yerkes \& Tijdens, 2010). Measuring affordability using the cost of childcare as a percentage of net family income (e.g., Keck et al., 2009; OECD, 2017b) is similarly problematic. Tax allowances presume parents have a taxable income (e.g., Immervoll \& Barber, 2006; Jaumotte, 2003); such figures therefore do not consider parents not in employment.

A salient aspect of affordability often not taken into consideration is the funding mechanism, i.e., the use of "supply-led" direct funding streams to providers, and/or the use of a "demand-priming approach," whereby parents receive financial help directly. For the latter, policy design regulates funding through means-testing or limits to parental/childcare fees using a sliding-fee scale (Immervoll \& Barber, 2006; Javornik, 2014). A "supply-led system" 
opens space for parents across socio-economic groups to access childcare via direct funding (Javornik, 2014; Leitner, 2003). In contrast, the demandpriming approach creates gaps in childcare capabilities as operating rules are set by providers to maximize profitability (Brennan et al., 2012). Parental fees increase, and the level of household income and/or childcare subsidy, tax allowance, and employers' assistance become crucial (Blackburn, 2012; Mamolo, Coppola, \& Di Cesare, 2011; Morgan, 2005). Another issue related to the demand-priming approach is that child-related tax deductions in some countries are not available at the time when parents incur childcare expenses, but in the following fiscal year (Immervoll \& Barber, 2006). Affordability is therefore particularly relevant for low-income parents (Capizzano \& Adams, 2004) and single mothers (Kreyenfeld \& Hank, 2000), whose purchasing power is comparatively lower to other groups. We address these issues by combining established data on childcare costs with an analysis of funding rules.

\section{Quality}

Quality is a measure of service experience but can be seen as subsidiary to service availability, accessibility, and affordability; unless childcare is accessible and affordable, quality is arguably less important. When there are issues with service quality, parents may not easily switch between childcare providers or an exit could be too costly (OECD, 2018). We know little about these interrelationships but high-quality service generates incentives for using nonfamilial childcare (Plantenga \& Remery, 2005). Measuring childcare quality is problematic because a standard definition is missing and there can be considerable differences between measurable qualities and how parents assess and experience quality (Janta, van Belle, \& Stewart, 2016; Keck et al., 2009; OECD, 2018).

Family policy research typically distinguishes between process quality at the organizational/staff level (e.g., what happens in the setting: the play and learning environment, child-teacher and child-child interaction) (Janta et al., 2016; OECD, 2018) and structural quality (e.g., maximum group size, childto-staff ratios, and the educational level of childcare staff) (Penn, 2013). Comparative data on process quality remains limited (Janta et al., 2016; OECD, 2018). Recent reports and a meta-analysis from the OECD (2017b, 2018) suggest few countries structurally gather data on process quality. The limited evidence available suggests that measures of process quality and its effects on children's development are inconsistent. Given these limitations, 
we focus on structural quality measurements of maximum group size, childto-staff ratios, and the educational level of childcare staff. Where possible, information on process quality is provided (OECD, 2018).

\section{Flexibility}

Flexibility in childcare service provision seems essential for childcare capability but suffers from limited understanding of what it entails, in addition to a lack of standardized data allowing for cross-country comparison. Flexibility is generally defined in relation to opening hours of childcare services. These determine the extent to which parents can use services (Gornick \& Meyers, 2003, p. 227) and deal with the constraints of time and distance (Emlen, 2010). Childcare services are not commonly available during nonstandard hours, which makes parents reliant on informal or commercial care. Lack of flexible childcare affects parents working non-standard or variable work hours, in education, looking for jobs (Grönlund \& Javornik, 2014; Javornik \& Ingold, 2015; Verhoef et al., 2016). However, flexibility in childcare services presumes usefulness for parents, rather than children. Whereas developmental studies suggest children do well in structured, consistent care environments, inflexible childcare services can make it difficult for parents to cope with the parameters of employment, schooling, or other activities (Javornik, 2014). The focus here is on parents' capabilities; to enable their childcare capabilities, services should be available on a full-time basis for at least 30 hours per week (Mills et al., 2014) all year-round, while providing parents sufficient freedom to choose the hours (OECD, 2007; Plantenga \& Remery, 2005, pp. 38-42). Ideally, we would develop an indicator using parents' self reports to capture this. However, such data are unavailable across countries, and thus we analyze guidelines and statutory frameworks related to the annual timetabling and opening hours, using Eurydice (2018) and single country data.

For all five policy aspects, we focus on publicly funded (non-familial) childcare for children from birth to compulsory school age in center-based day care. We evaluate the situation from a dual-earner couples' perspective while acknowledging that families are much more diverse. 


\section{Empirical Applications to Childcare Services}

Analysing childcare policies along the key aspects of childcare services from a capability perspective demonstrates how diversified national childcare policies are and how their policy designs vary more within our de-familialized country cluster than suggested by "varieties of familialism" scholarship (see Yerkes \& Javornik, 2019). While some patterns are discernible within the public provision and marketized groups of countries, considerable differences exist within and between subgroups, which can have significant consequences for childcare capability. Building on an earlier empirical analysis of six countries (Yerkes \& Javornik, 2019), we go more in-depth in our analysis here to highlight the potential consequences of variation in childcare service availability, accessibility, affordability, quality, and flexibility in two systems characteristic of a public provision (Sweden) and marketized provision (UK) (for more countries see Yerkes and Javornik, 2019). The data are summarized in Table 7.1.

In Sweden, childcare is primarily offered as a public service. The provision is decentralized as the legal responsibility of local municipalities, but is nationally regulated, coordinated, and monitored (Gislason \& Eydal, 2011; Javornik, 2014). Admission criteria are nationally regulated as well, with central capacity planning, which ensures uniformity and coherence across settings and municipalities. Children are largely enrolled in full-time childcare (30+ hours a week). While few children under 1 year attend childcare given the Swedish system of generous parental leave, nearly all children aged 3 to compulsory school age attend formal care (96.2\%). Unlike Sweden, part-time childcare is the norm in the UK, and market provision is the dominant form of childcare service delivery (Penn, 2013). Responsibility for childcare services is less clear-cut than in Sweden, and is divided between central and local governments dependent upon the age group concerned (Gislason \& Eydal, 2011, p. 73). There is an array of actors operating across private, voluntary, and non-for-profit organizations and local council services in the UK (Lloyd, 2015), resulting in significant regional variation in childcare provision, with London and the South East offering the most expensive under-5 childcare (Javornik \& Ingold, 2015). The expectation is that the market mechanism creates incentives for providers to offer more choice and competitive pricing, leading to a better balance between supply and demand (Brennan et al., 2012). However, 30\% of parents report insufficient childcare in their area (DfE, 2014). By and large, the dominance of market mechanisms, especially for children under 3, leads to inequality in capabilities. Although not explicitly cast in gendered terms, variant availability negatively 


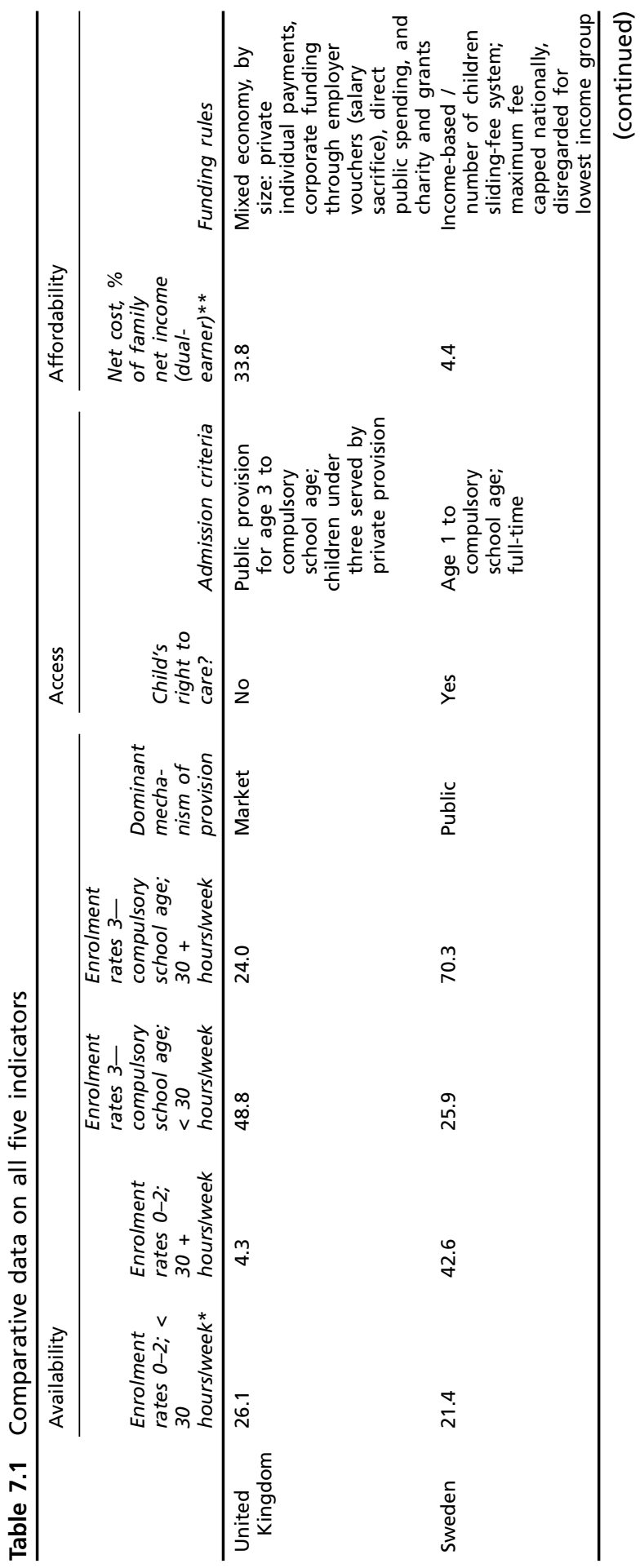




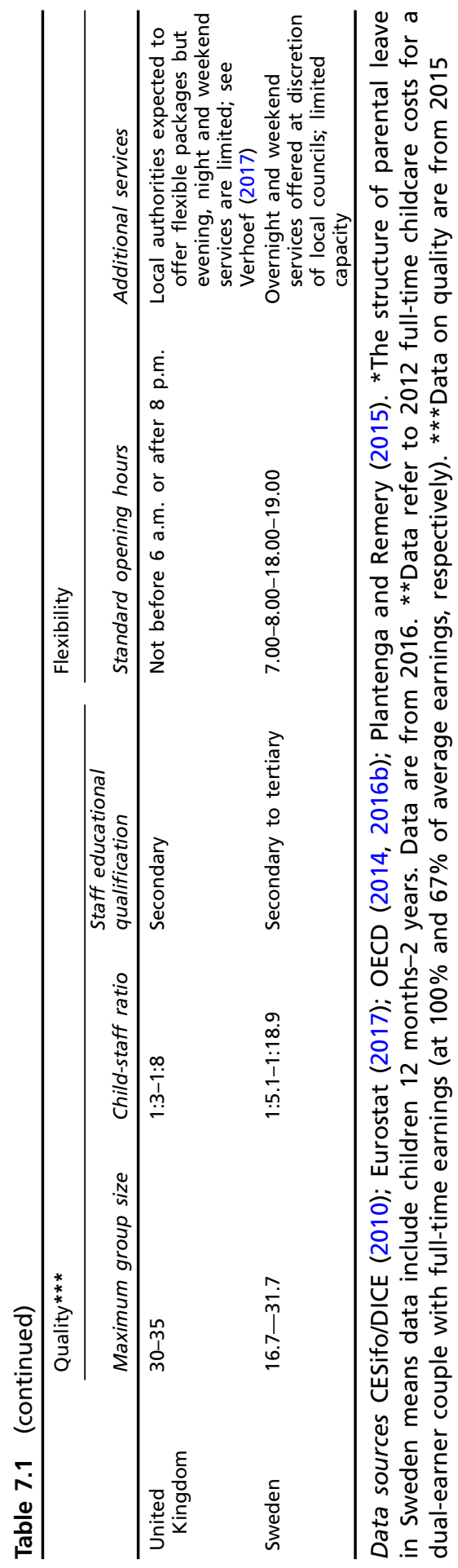


affects women's capabilities who need to reduce working hours or withdraw from the labor market in order to provide childcare. Namely, in this one-anda-half earner model, women take on higher parenting and care responsibilities than men (Lewis, 2009). From a class perspective, policy incoherence across settings reduces childcare capabilities because private businesses are focused on profitability (OECD, 2018); this can diminish childcare capabilities of low-income parents in particular. In Sweden, in contrast, public provision that is centrally regulated and overseen improves childcare capability along gender and class lines.

Sweden similarly offers better accessibility than the marketized UK, providing childcare as a child's right and with a guarantee (without reasonable delay), although this is exceptional, even among public-mechanism countries (Yerkes \& Javornik, 2019). This is not the case in the UK. Sweden offers childcare services to children aged one to compulsory school age on a fulltime basis. In the UK, childcare (early education) is essentially available for children aged 0-14, and up to age 18 for disabled children (OECD, 2015). However, children under two are not entitled to public childcare and children aged 3-4 have the right to 30 hours for 38 weeks/year since 2018 (Javornik \& Ingold, 2015).

In both countries, however, inequalities in childcare capabilities can arise from limitations in childcare accessibility. In Sweden, paid parental leave and childcare services are contiguous in principle. But in practice, most places become available in September, when older children go to school (Grönlund \& Javornik, 2014; Javornik, 2014; Javornik \& Kurowska, 2017). This gap can disrupt childcare capabilities, an issue pertinent for low-income parents. Similarly, the absence of well-paid parental leave in the UK can lead to reduced childcare capabilities across gender and class. The UK's maternity leave offers the lowest replacement rates in the OECD, of around one-third of gross average earnings (OECD, 2017a) and Shared Parental Pay (the statutory payment provided to eligible parents taking up Shared Parental Leave during the first 37 weeks of leave) adopts the same basic rate. While employers can top-up government payments by offering extra-statutory (enhanced) benefits (e.g., sickness, maternity, paternity, and shared parental pay) up to one year, these are at the discretion of employers and seldom offered to fathers (Javornik \& Oliver, 2019). Thus, fathers in particular are missing out on a potential conversion factor to draw on parental leave to achieve their preferred childcare arrangement. This widens the gap between parental leave and public childcare, further diminishing capabilities of mothers in particular. This aggrevates class divisions considering a recourse to paid parental 
leave is not a real choice when alternative childcare is unavailable (Kurowska \& Javornik, 2019).

A significant difference exists between public-mechanism and marketized countries in relation to affordability (OECD, 2017a). Childcare is affordable in Sweden, where dual-earner couples spend a marginal share (4.4\%) of net family income on childcare services. Sweden uses an income-based sliding-fee system; maximum fees are set by the state, with a lower payment ceiling and discounts for certain groups (e.g., low-income parents, single parents, and large families). Municipalities can introduce discounts and charge differently within the national guidelines. Such regional variation could diminish parents' childcare capability across municipalities, particularly for middle-income families: while high-income families benefit from the ceiling, low-income families can have fees waived completely. Unlike Sweden, the UK combines part-time, universal free places with demand-led funding through the tax and benefit systems for pre-school children. This results in parents paying an exorbitant $33.8 \%$ of family net income per month for outof-pocket childcare expenses, versus the $12.6 \%$ paid on average by parents in OECD countries. In the UK open market, fees are set by providers to maximize profitability. They can receive financial help directly; other subsidies go directly to childcare providers (Javornik \& Ingold, 2015). Retrospective reimbursement through the tax and benefits system is inefficient and a deterrent for many families, resulting in diminished childcare capability. In reality, prohibitive childcare costs further hinder capabilities across social class and gender, when low-income families are forced to opt for family care, usually taken up by mothers.

In relation to structural quality, there is a clear division between Sweden and the UK. Sweden has smaller playgroups led by trained staff. All staff are required to have at least secondary or tertiary education, with the focus on a pedagogical service centered on children's development. While the UK has larger group sizes (30-35 children per group), staff-child ratios are lower (Table 7.1). Staff are not required to have secondary or tertiary education, and there are no mandatory requirements for in-service training (Penn, 2013). In the profit-driven childcare market, providers are motivated to minimize costs. With regulated child-staff ratios, cost minimalization can be achieved by employing a less qualified workforce (Brennan et al., 2012; Penn, 2013). The focus on profitability and childcare as an employment instrument leads to lower qualification standards, resulting in serious quality issues. When childcare is of lower quality, childcare capabilities of parents are reduced across gender and class. Attitudes toward the use of formal childcare-influenced by perceptions of quality-are more positive in Sweden than in the 
UK. While the use of formal childcare is becoming increasingly accepted in the UK, lower socio-economic groups are less positive toward public childcare, leading to gendered patterns of care, and thus inequality in capabilities (Fagan \& Norman, 2012). Additionally, low-income parents may have fewer skills needed to "navigate the system" in assessing differences in quality and ultimately lack the financial resources to purchase higher quality childcare (Brennan et al., 2012). Both countries' regulatory systems outline process quality regulations and standards; this generally includes health and safety requirements, space, staff training, staff-child ratios, and curricula. In sum, unlike Sweden, the UK faces significant childcare quality problems, with an uncomfortable relationship between market provision and quality (Brennan et al., 2012; Lloyd, 2015). Childcare providers perform below the OECD average on quality, particularly in relation to staff skills and parental involvement (Taguma, Litjens, \& Makowiecki, 2012). In Sweden, childcare quality is higher, with communal obligations to delivering reliable, high-quality childcare, with equity more pronounced than choice (Penn, 2013).

Lastly, our analysis suggests that limited service flexibility affects childcare capabilities across both countries, with notable differences. In Sweden, childcare is generally typified and standardized, i.e., largely compatible with national standard work hours (Grönlund \& Javornik, 2014). Statutory frameworks set no requirements about opening hours, which are set by municipalities. Childcare centees run on a full-time basis, for 11 hours a day on weekdays throughout the year. Providers can offer weekend or overnight services at the discretion of local councils. In the UK, opening hours are not covered by statutory frameworks but are left to providers. Statutory guidance does support flexibility in service delivery and local authorities are expected to offer flexible packages of free hours but of not more than 10 hours (no minimum session length). The absence of childcare outside standard hours (there is no service before 6 am or after $8 \mathrm{pm}$ ) limits parents' capabilities, especially in non-urban areas, where out-of-hours care is most limited (Grönlund \& Javornik, 2014; Javornik \& Ingold, 2015). In the UK, this leads to high demand for flexible working arrangements, in particular among women and also negatively affects parents in education or training. 


\section{Discussion and Conclusion}

Contemporary comparative family policy research continues to face difficulties in conceptualizing and operationalizing family policies for cross-national research given their variations and complexities. This chapter offered an alternative analytical framework by conceptualizing family policy using the capability approach. We focused here on childcare services, in particular service accessibility, availability, affordability, quality, and flexibility. We suggest that family policy designs shape parents' capabilities in distinct ways. In relation to childcare, public service provision (e.g., Sweden) generally improves parents' childcare capabilities. In marketized countries (e.g., the UK), parents' capabilities are significantly diminished along gender and class lines. Additionally, our analysis highlights tensions, such as potential regional variation in childcare affordability in Sweden. We note that limited flexibility is an overarching problem across both systems, which is particularly problematic for parents in non-standard jobs (Verhoef, 2017), in training or education, or seeking jobs. A further advantage in applying the capability approach to comparative family policy research is the ability to conceptualize potential impact of policy across key individual-level factors. As our analysis demonstrates, distinct public and market approaches to childcare service provision have different gender and class consequences, which the capability approach is particularly apt to capture. Similarly, future studies could emphasize other conversion factors, such as ethnicity, age or individual health and well-being. A further potential for future comparative family policy analysis lies in the capability approach's ability to highlight the salient aspects of policy design for comparative purposes (as shown here), or to focus on conceptualizing the linkages between such policy design features.

In sum, the capability approach provides a valuable analytical instrument for comparative family policy analysis. Its analytical power is in moving beyond the more established approaches such as defamilialism, which mask key distinctions between public and market service provision. It facilitates a more nuanced conceptualization of family policy, thus revealing parents' real opportunities in relation to policy design. Furthermore, it recognizes multiple lifestyles and values, thus moving beyond implicit commodification assumptions; this opens up analytical space to include parents' appreciation of multiple care arrangement opportunities. Conceptually, the capability approach provides a promising way forward in comparative family policy research. Empirically, however, challenges remain. Optimal commensurable measures are not equally available across countries, which limits more nuanced cross-national comparative family policy analysis. As countries 
continue to invest more in childcare (Pavolini \& Van Lancker, 2018), it is necessary to also invest in measuring the effects of childcare, both in terms of outcomes as well as parents' capabilities. Similar investments in other areas of family policy are needed as well.

Acknowledgements The research leading to these results has received funding from the European Union's Horizon 2020 research and innovation programme under grant agreement No. 730998, InGRID-2-Integrating Research Infrastructure for European expertise on Inclusive Growth from data to policy.

\section{References}

Baxter, J. (2000). The joys and justice of housework. Sociology, 34(4), 609-631. Béland, D. (2005). Ideas and social policy: An institutionalist perspective. Social Policy and Administration, 39(1), 1-18.

Béland, D. (2016). Ideas and institutions in social policy research. Social Policy \& Administration, 50(6), 734-750.

Blackburn, P. (2012). Future directions for a mature UK childcare market. In E. Lloyd \& H. Penn (Eds.), Childcare markets (pp. 43-60). Bristol: Policy Press.

Bonoli, G., \& Reber, F. (2010). The political economy of childcare in OECD countries: Explaining cross-national variation in spending and coverage rates. European Journal of Political Research, 49(1), 97-118.

Brennan, D., Cass, B., Himmelweit, S., \& Szebehely, M. (2012). The marketisation of care: Rationales and consequences in nordic and liberal care regimes. Journal of European Social Policy, 22(4), 377-391.

Capizzano, J., \& Adams, G. (2004). Children in low-income families are less likely to be in center-based child care. Washington, DC: The Urban Institute.

Chatrakul, U., Ayudhya, N. A., Prouska, R., \& Beauregard, T. A. (2017). The impact of global economic crisis and austerity on quality of working life and work-life balance: A capabilities perspective. European Management Review, $16(4), 847-862$.

Ciccia, R., \& Bleijenbergh, I. (2014). After the male breadwinner model? Childcare services and the division of labor in european countries. Social Politics, 21(1), 50-79.

Daguerre, A. (2006). Childcare policies in diverse European welfare states: Switzerland, Sweden, France and Britain. In K. Armingeon \& G. Bonoli (Eds.), The politics of post-industrial welfare states: Adapting post-war social policies to new social risks (pp. 227-247). Oxon \& New York, NY: Routledge.

den Dulk, L., \& Yerkes, M. A. (2016). Capabilities to combine work and family in The Netherlands: Challenging or reinforcing the one-and-a-half Earner model? Japanese Journal of Family Sociology, 28(2), 180-192. 
DfE. (2014). Childcare and early years survey of parents 2012-13. London: DfE.

DICE. (2010). DICE: Database for Institutional Comparisons in Europe. https:// b2share.eudat.eu/records/c50b0bd8a5434f6fb19853769a75ad9a

Emlen, A. C. (2010). Solving the childcare and flexibility puzzle: How working parents make the best feasible choices and what that means for public policy (Paper No. 40).

Esping-Andersen, G. (2009). The incomplete revolution: Adapting to women's new roles. Cambridge: Polity Press.

Eurostat. (2017). European union labour force survey. Brussels: Eurostat.

Eurydice. (2018). National education systems: Early childhood education and care. Brussels: European Commission.

Eydal, G. B., \& Rostgaard, T. (2011). Gender equality revisited-Changes in nordic childcare policies in the 2000s. Social Policy \& Administration, 45(2), 161-179.

Fagan, C., \& Hebson, G. (2005). Making work pay debates from a gender perspective: A comparative review of some recent policy reforms in thirty European countries. Brussels: European Commission.

Fagan, C., \& Norman, H. (2012). Trends and social divisions in maternal employment patterns following maternity leave in the UK. International Journal of Sociology and Social Policy, 32(9/10), 544-560.

Fahlén, S. (2013). Capabilities and childbearing intentions in Europe. European Societies, 15(5), 639-662.

Giddens, A. (1984). The constitution of society: Outline of the theory of structuration. Cambridge: Polity Press.

Ginsburg, N. (2004). Structured diversity: A framework for critically comparing welfare states? In P. Kennett (Ed.), A handbook of comparative social policy (pp. 201-216). Cheltenham, UK: Edward Elgar.

Gislason, I. V., \& Eydal, G. B. (2011). Parental leave, childcare and gender equality in the nordic countries. Copenhagen: Nordic Council of Ministers.

Goerne, A. (2010). The capability approach in social policy analysis: Yet another concept? (Working Papers on the reconciliation of work and welfare in Europe). Edinburgh: RECWOWE Publication, Dissemination and Dialogue centre. http://doi.org/10.2139/ssrn.1616210.

Gornick, J. C., \& Meyers, M. (2003). Families that work: Policies for reconciling parenthood and employment. New York, NY: Russell Sage Foundation.

Gornick, J. C., Meyers, M. K., \& Ross, K. E. (1998). Public policies and the employment of mothers: A cross-national study. Social Science Quarterly, 79(1), 35-54.

Grönlund, A., \& Javornik, J. (2014). Great expectations: Dual-earner policies and the management of work-family conflict: The examples of Sweden and Slovenia. Families, Relationships and Societies, 3(1), 51-65. 
Hobson, B. (ed.). (2014). Worklife balance: The agency and capabilities gap. Oxford: Oxford University Press.

Hobson, B. (2018). Gendered dimensions and capabilities: Opportunities, dilemmas and challenges. Critical Sociology, 44(6), 883-898.

Hobson, B., Fahlen, S., \& Takacs, J. (2011). Agency and capabilities to achieve a work-life balance: A comparison of Sweden and Hungary. Social Politics: International Studies in Gender, State \& Society, 18(2), 168-198.

Hook, J. L. (2015). Incorporating class into work-family arrangements: Insights from and for three worlds. Journal of European Social Policy, 25(1), 14-31.

Hvinden, B., \& Halvorsen, R. (2018). Mediating agency and structure in sociology: What role for conversion factors?. Critical Sociology, 44(6), 865-881.

Immervoll, H., \& Barber, D. (2006). Can parents afford to work? Childcare costs, tax-benefit policies and work incentives (Discussion Paper No. 1932). Bonn: IZA.

Janta, B., Van Belle, J., \& Stewart, K. (2016). Quality and impact of centre-based early childhood education and care. Santa Monica, CA: Rand Corporation.

Jaumotte, F. (2003). Labour force participation of women: Empirical evidence on the role of policy and other determinants in OECD countries. OECD Economic Studies, 37(2), 51-108.

Javornik, J. (2014). Measuring state de-familialism: Contesting post-socialist exceptionalism. Journal of European Social Policy, 24(3), 240-257.

Javornik, J., \& Ingold, J. (2015). A childcare system fit for the future? In L. Foster, A. Brunton, C. Deeming, \& T. Haux (Eds.), In Defence of welfare 2 (pp. 75-78). Bristol: Policy Press.

Javornik, J., \& Kurowska, A. (2017). Parental leave as real opportunity structure for families and the source of gender and class inequalities. Social Policy \& Administration, 51(4), 617-637.

Javornik, J., \& Oliver, L. (2019). Converting shared parental leave into shared parenting: The role of employers and use of litigation by employees in the UK. In M. A. Yerkes, J. Javornik, \& A. Kurowska (Eds.), Social policy and the capability approach: Concepts, measurement and application. Bristol: Policy Press.

Jensen, C. (2009). Institutions and the politics of childcare services. Journal of European Social Policy, 19(1), 7-18.

Keck, W., Hessel, P., \& Saraceno, C. (2009). Database on intergenerational policy indicators: Methodological report. Berlin: Wissenschaftszentrum Berlin für Sozialforschung.

Korpi, W., Ferrarini, T., \& Englund, S. (2013). Women's opportunities under different family policy constellations: Gender, class, and inequality tradeoffs in western countries re-examined. Social Politics, 20(1), 1-40. 
Koslowski, A., \& Kadar-Satat, G. (2019). Fathers at work: Explaining the gaps between entitlement to leave policies and uptake. Community, Work \& Family, 22(2), 129-145.

Kreyenfeld, M., \& Hank, K. (2000). Does the availability of childcare influence the employment of mothers? Findings from western Germany. Population Research and Policy Review, 19(4), 317-337.

Kurowska, A. (2018). (De)familialization and (de)genderization-Competing or complementary perspectives in comparative policy analysis? Social Policy \& Administration, 52(1), 29-49.

Kurowska, A., \& Javornik, J. (2019). Comparative social policy analysis of parental leave policies through the lenses of capability approach. In M. A. Yerkes, J. Javornik, \& A. Kurowska (Eds.), Social policy and the capability approach: Concepts, measurement and application. Bristol: Policy Press.

Lambert, P. A. (2008). The comparative political economy of parental leave and child care: Evidence from twenty OECD countries. Social Politics: International Studies in Gender, State \& Society, 15(3), 315-344.

Leitner, S. (2003). Varieties of familialism: The caring function of the family in comparative perspective. European Societies, 5(4), 353-375.

Lewis, J. (2009). Work-family balance, gender and policy. Chelthenham: Edward Elgar.

Lister, R. (1997). Citizenship: Feminist perspectives. New York, NY: New York University Press.

Lloyd, E. (2015). Early childhood education and care policy in England under the coalition government. London Review of Education, 13(2), 144-156.

Mamolo, M., Coppola, L., \& Di Cesare, M. (2011). Formal childcare use and household socio-economic profile in France, Italy, Spain and UK. Population Review, 50(1), 170-194.

Mätzke, M. J., Brokking, P., Anntonen, A., \& Javornik, J. (2017). Public policy conceptions: Priorities of social service provision in Europe. In F. Martinelli, A. Anntonen, \& M. J. Mätzke (Eds.), Social services disrupted: Changes, challenges and policy implications for Europe in times of austerity (pp. 71-91). Cheltenham: Edward Elgar.

Mead, G. H. (1934). Mind, self, and society: From the standpoint of a social behaviorist. Chicago, IL: University of Chicago Press.

Mills, M. C., Präg, P., Tsang, F., Begall, K., Derbyshire, J., Kohle, L., \& Hoorens, S. (2014). Use of childcare in the EU member states and progress towards the Barcelona targets. Brussels: European Union.

Morgan, K. J. (2005). The production of child care: How labor markets shape social policy and vice versa. Social Politics, 12(2), 243-263.

Multilinks. (2011). Multilinks database on intergenerational policy indicators (Version 2.0). Berlin: Multilinks project and Wissenschaftszentrum Berlin für Sozialforschung. Accessed 5 Mar 2018. 
North, D. C. (1990). Institutions, institutional change and economic performance. Cambridge: Cambridge University Press.

Nussbaum, M. C. (1987). Nature, function and capability: Aristotle on political distribution (Working Paper No. 31). Rhode Island, RI: Providence.

Nussbaum, M. C. (2000). Women and human development: The capabilities approach. Cambridge: Cambridge University Press.

Nussbaum, M. C. (2011). Creating capabilities: The human development approach. Massachusetts, MA: Harvard University Press.

OECD. (2007). Babies and bosses: Reconciling work and family life: A synthesis of findings for OECD countries. Paris: OECD.

OECD. (2014). Society at a Glance 2014. OECD Publishing. https://doi.org/10. 1787/soc_glance-2014-en.

OECD. (2015). Starting strong IV. Paris: OECD.

OECD. (2016a). PF3.1: Public spending on childcare and early education. https://www.oecd.org/els/soc/PF3_1_Public_spending_on_childcare_and_ early_education.pdf.

OECD. (2016b). Society at a Glance 2016. OECD Publishing. https://doi.org/10. 1787/9789264261488-en.

OECD. (2017a). OECD family database. Paris: OECD.

OECD. (2017b). Starting strong 2017: Key OECD indicators on early childhood education and care. Paris: OECD.

OECD. (2018). Engaging young children lessons from research about quality in early childhood education and care. Paris: OECD.

Pavolini, E., \& Van Lancker, W. (2018). The Matthew effect in childcare use: A matter of policies or preferences? Journal of European Public Policy, 25(6), 878893.

Penn, H. (2013). Childcare markets: Do they work? In E. Lloyd \& H. Penn (Eds.), Childcare markets: Can they deliver an equitable service? (pp. 19-42). Bristol: Policy Press.

Plantenga, J., \& Remery, C. (2005). Reconciliation of work and private life: A comparative review of thirty European countries. Brussels: Directorate-General for Employment Social Affairs and Equal Opportunities, European Commission.

Plantenga, J., \& Remery, C. (2009). The provision of childcare services: A comparative review of 30 European countries. Brussels: European Communities.

Plantenga, J., \& Remery, C. (2013). Childcare services for school age children: A comparative review of 33 countries. Brussels: European Communities.

Plantenga, J., \& Remery, C. (2015). Provision of childcare services: A comparative review of European member states. CESifo DICE Report, 13(1), 20-24.

Robeyns, I. (2005). The capability approach: A theoretical survey. Journal of Human Development, 6(1), 93-117. 
Robeyns, I. (2017). Wellbeing, freedom and social justice: The capability approach re-examined. Cambridge: Open Book Publishers. http://doi.org/10.11647/OBP. 0130.

Saraceno, C. (2011). Childcare needs and childcare policies: A multidimensional issue. Current Sociology, 59(1), 78-96.

Saraceno, C., \& Keck, W. (2010). Can we identify intergenerational policy regimes in Europe? European Societies, 12(5), 675-696.

Sen, A. (1992). Inequality reexamined. Cambridge, MA: Harvard University Press.

Sen, A. (1999a). Commodities and capabilities. Oxford: Oxford University Press.

Sen, A. (1999b). Development as freedom. Oxford: Oxford University Press.

Sen, A., Hanžek, M., \& Javornik, J. (2002). Ekonomija blaginje: Izbrane razprave. Ljubljana: Založba.

Shaw, S. M. (1994). Gender, leisure, and constraint: Towards a framework for the analysis of women's leisure. Journal of Leisure Research, 26(1), 8-22.

SPIN. (2019). Social Policy Indicators Database. University of Stockholm, SOFI: https://www.sofi.su.se/spin/.

Steiber, N., \& Haas, B. (2009). Ideals or compromises? The attitude-behaviour relationship in mothers' employment. Socio-Economic Review, 7(4), 639-668.

Taguma, M., Litjens, I., \& Makowiecki, K. (2012). Quality matters in early childhood education and care: United Kingdom (England). Paris: OECD.

Thompson, L. (1991). Family work: Women's sense of fairness. Journal of Family Issues, 12(2), 181-196.

van Huizen, T. M., \& Plantenga, J. (2015). Universal child care and children's outcomes: A meta-analysis of evidence from natural experiments (Discussion Paper Series No. 15(13)) Utrecht: Tjalling C. Koopmans Research Institute.

Verhoef, M. (2017). Work-schedules, childcare and well-being. Utrecht: Utrecht University.

Verhoef, M., Tammelin, M., May, V., Rönkä, A., \& Roeters, A. (2016). Childcare and parental work schedules: A comparison of childcare arrangements among Finnish, British and Dutch dual-earner families. Community, Work \& Family, 19(3), 261-280.

Yerkes, M. A., \& den Dulk, L. (2015). Arbeid-en-zorgbeleid in de participatiesamenleving. Tijdschrift Voor Arbeidsvraagstukken, 2015(31), 510-528.

Yerkes, M. A., \& Javornik, J. (2019). Creating capabilities: Childcare policies in comparative perspective. Journal of European Social Policy, 29(4), 529-544.

Yerkes, M. A., Hoogenboom, M., \& Javornik, J. (2019, May 23-25). Wherés the community in community, work and family? A capabilities framework. Paper presented at the 8th International Community, Work \& Family Conference, Malta.

Yerkes, M. A., Javornik, J., \& Kurowska, A. (eds). (2019). Social policy and the capability approach: Concepts, measurement and application. Bristol: Policy Press. 
Yerkes, M. A., Martin, B., Baxter, J., \& Rose, J. (2017). An unsettled bargain? Mothers' perceptions of justice and fairness in paid work. Journal of Sociology, 53(2), 476-491.

Yerkes, M. A., \& Tijdens, K. (2010). Social risk protection in collective agreements: Evidence from The Netherlands. European Journal of Industrial Relations, 16 (4), 369-383.

Open Access This chapter is licensed under the terms of the Creative Commons Attribution 4.0 International License (http://creativecommons.org/licenses/by/4.0/), which permits use, sharing, adaptation, distribution and reproduction in any medium or format, as long as you give appropriate credit to the original author(s) and the source, provide a link to the Creative Commons licence and indicate if changes were made.

The images or other third party material in this chapter are included in the chapter's Creative Commons licence, unless indicated otherwise in a credit line to the material. If material is not included in the chapter's Creative Commons licence and your intended use is not permitted by statutory regulation or exceeds the permitted use, you will need to obtain permission directly from the copyright holder.

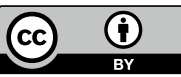

